\title{
23. CARTE DU CIEL
}

Président: W. Dieckvoss.

Vice-President: P. Lacroute.

Organizing Committee: P. Couderc, A. N. Dejč, P. Herget, H. Kox, W. J. Luyten, P. Sémirot, H. W. Wood.

There seems to be a consensus of opinion that the useful life of the commission has come to an end with the achievement of the principal aim of the historical task of the Carte du Ciel, presenting an overall picture of the Heavens as to positions of the fixed stars up to a definite limiting magnitude. The French presidents in succession with great energy, supported by the IAU, succeeded in overcoming all obstacles and in finishing the printed Astrographic Catalogue. Remaining tasks of deriving definitive plate constants, eventually deriving reliable proper motions of all stars in the programme evidently rests with individual observatories or at other commissions of the Union within their proper frame of activities.

Following a suggestion presented at the meeting of the Executive Committee in September 1969 a decision was reached to abolish the Commission 23 proper by merging it with Commission 24 (Stellar parallax and proper motion), and a working group in the latter commission would become a suitable means to continue work on data furnished by the Astrographic Catalogue.

Several of those observatories still in possession of Carte du Ciel-astrographs are going on with proper motion (p.m.) work in their zones or are preparing to do so. The application of the astrographs to the programme of attachment of stars to galaxies according to A. N. Dejč's method is in progress.

P. Kustaanheimo of Helsinki reports the astrograph of the Helsingfors zone of the Carte du Ciel and the Astrographic Catalogue (A.C.) being in excellent condition after some modernization. The collection of plates, the oldest dating back to 1892, is well preserved. After transferring the work on positions of artificial satellites to other institutions of the country the observatory now is willing to continue its proper motion work on faint stars, work that was stopped shortly after the war. There is a threat to close down the observatory by the authorities who would like to use the observatory buildings for offices. As the observatory is well renowned for its high standard in published results - the Helsingfors zone of the A.C. is one of the most accurate in both hemispheres a closing down would be detrimental to highly useful long range programmes on faint stars, and a resolution of the IAU asking the authorities of Finland to support the observatory in its tasks would be most welcome.

B. J. Harris reports re-installation of the Perth-A.C.-astrograph at the new observatory site Bickley. Re-evaluation of plate constants and tests for a total re-observation of the Perth zone are in progress.

H. Wood of Sydney announces completion of the Sydney section of the A.C., the last volume, now in print, will contain a history of the work. It will include particulars as to methods applied and as to information and tables to be used with the catalogue.

A. N. Dejč of Pulkovo reports as to the programme of attachment of stars to galaxies by means of the A.C.-astrographs:

1. Aux observatoires de Poulkovo, Moscou et Taschkent on a commencé de photographier les aires choisies dans la zone $+90^{\circ}$ à $-5^{\circ}$ et plus australes jusqu'à $-25^{\circ}$ de déclinaison pour la seconde époque ayant un intervalle de 20 ans.

2. Le programme photographique des galaxies de la zone $-5^{\circ}$ à $-25^{\circ}$ a été fini à San Fernando pour la première époque et sera bientôt accompli pour la zone $-25^{\circ}$ à $-90^{\circ}$ à Santiago et à Perth (Bickley).

Chr. de Vegt of Hamburg used data of the A.C. extensively for p.m. work on open clusters. Original plates lent by O'Connell of Castel Gandolfo were measured with the Mann comparator 
of Hamburg Observatory. The mean errors of presentation of the AGK $2 / 3$ reference positions were diminished by 25 to $30 \%$ as compared with the original coordinates as printed in the A.C. Rome-Vatican. The association Cep. III is being studied in collaboration with A. Blaauw by remeasuring the original Vatican-plates with the automatic machine of K. Strand at the U.S.-Naval Observatory Washington.

Eichhorn and Gatewood in 1967 published new plate constants for the Northern Hyderabad zone of the A.C., $+35^{\circ}$ to $+40^{\circ}$.

Work on definitive plate constants in the zones covered by AGK $3\left(-2.5\right.$ to $\left.+90^{\circ}\right)$ went according to plan in Hamburg (H. Kox, A. Günther). The results for the zones Greenwich, RomeVatican, Catania, Helsingfors are in print (Astronomy and Astrophysics, a European Journal). In France the work under supervision by P. Lacroute may proceed when the AGK 3 will become available south of $+36^{\circ}$ (approximately in February 1970).

North of $+40^{\circ}$ the A.C. positions of the reference stars from AGK 3 after due correction on account of systematic errors and by applying definitive plate constants are being used for a general catalogue of positions and proper motions (W. Dieckvoss).

TOPICS FOR DISCUSSIONS AT THE XIV GENERAL ASSEMBLY

Historical Survey of the Carte du Ciel (P. Sémirot)

Report on definitive plate constants,

Bergedorf (H. Kox)

France (P. Lacroute)

Magnitude equation of faint stars in the A.C.

Remeasurement of preserved old plates by modern, preferably automatic, machines.

Proper motions of faint stars following repetition of old zones, preferably by modern wide angle objectives, which are less prone to optical aberrations than the original A.C. objectives.

Transformation of A.C. data into machine-readable form in an international scale.

Application of A.C. data to p.m. of clusters.

Coordination with p.m. in Kapteyn's selected areas.

Situation in Helsinki, preparation of a resolution.

Merging with Commission 24 in a joint session, appointment of a working group concerning itself with A.C., as proposed by P. Lacroute.

W. DIECKVOSS

President of the Commission 